\title{
Increasing coral calcification in Orbicella faveolata and Pseudodiploria strigosa at Flower Garden Banks, Gulf of Mexico
}

\author{
Derek P. Manzello ${ }^{1}$ • Graham Kolodziej $^{2,3} \cdot$ Amanda Kirkland $^{4}$ • \\ Nicole Besemer ${ }^{2,3} \cdot$ Ian C. Enochs ${ }^{2}$
}

Received: 15 December 2020/ Accepted: 4 May 2021/Published online: 13 May 2021

(C) This is a U.S. government work and not under copyright protection in the U.S.; foreign copyright protection may apply 2021

\begin{abstract}
Coral reefs are globally in decline and western Atlantic reefs have experienced the greatest losses in live coral cover of any region. The Flower Garden Banks (FGB) in the Gulf of Mexico are high-latitude, remote reefs that are an outlier to this trend, as they have maintained coral cover $\geq 50 \%$ since at least 1989 . Quantifying the long-term trends in coral growth of key reef-building coral species, and the underlying environmental drivers, leads to a better understanding of local sensitivities to past changes that will ultimately allow us to better predict the future of reef growth at FGB. We obtained coral cores and constructed growth records for two of the most abundant hermatypic coral species at FGB, Pseudodiploria strigosa and Orbicella faveolata. Our records cover $57 \mathrm{yrs}$ of
\end{abstract}

Topic Editor Mark Vermeij

Supplementary Information The online version contains supplementary material available at https://doi.org/10.1007/s00338021-02108-8.

Derek P. Manzello

Derek.Manzello@noaa.gov

1 Coral Reef Watch, Center for Satellite Applications and Research, Satellite Oceanography and Climate Division, U.S. National Oceanic and Atmospheric Administration, College Park, MD 20740, USA

2 Atlantic Oceanographic and Meteorological Laboratories (AOML), NOAA, 4301 Rickenbacker Cswy., Miami, FL 33149, USA

3 Rosenstiel School of Marine and Atmospheric Science, Cooperative Institute for Marine and Atmospheric Studies, University of Miami, 4600 Rickenbacker Cswy., Miami, FL 33149, USA

4 University of New Orleans, 2000 Lakeshore Drive, New Orleans, LA 70148, USA growth for $P$. strigosa (1957-2013) and $45 \mathrm{yrs}$ for $O$. faveolata (1970-2014). Linear extension and calcification rates of both species have increased significantly, but skeletal density did not change over the respective time periods. Extension and calcification data of both species combined were negatively correlated with the discharge from the Atchafalaya River, but positively correlated with maximum sea surface temperatures (SST). These data provide evidence that runoff from the Atchafalaya River impacts FGB corals and is a major control on coral growth at FGB. The increase in growth at FGB can be attributed to the significant warming trend in maximum monthly SSTs. Given the warming trend and recent increase in severity of bleaching at FGB, the prognosis is that bleaching events will become more deleterious with time, which will lead to a breakdown in the positive relationship between coral growth and maximum SST. This study provides further evidence that some high-latitude, cooler reef sites have experienced a stimulation in coral growth with ocean warming.

Keywords Linear extension - Skeletal density - Ocean warming · Schlerochronology · National Coral Reef Monitoring Program $\cdot$ Atchafalaya River

\section{Introduction}

Coral reefs are in decline worldwide and western Atlantic reefs are among the most degraded in the world (Gardner et al. 2003; Alvarez-Filip et al. 2009; Eakin et al. 2010; Perry et al. 2013, 2018). Live coral cover in the western Atlantic has declined by about $80 \%$ over the past 40 yrs and has not shown any signs of recovery (Gardner et al. 2003; Jackson et al. 2014; Contreras-Silva et al. 2020). 
More than one-third of sites that were surveyed in the Bahamas, Grand Cayman, Belize, and Bonaire from 2010 to 2012 were found to be net erosional (Perry et al. 2013). On these reefs, $\mathrm{CaCO}_{3}$ production decreased to $50 \%$ below historical averages, owing to the loss of live coral throughout the region, particularly the major reef-building acroporids and Orbicella annularis species complex (Perry et al. 2013). Of those reefs not actively eroding, many are in an "accretionary stasis" (close to $\mathrm{CaCO}_{3}$ budget neutral), which means that many reef framework structures in the western Atlantic are losing structural complexity, impairing the delivery of critical ecosystem services and the ability of reefs to keep up with sea level rise (AlvarezFilip et al. 2009; Perry et al. 2018).

An outlier to this region-wide decline are the high-latitude, remote coral reefs of the Flower Garden Banks (FGB) in the northwest Gulf of Mexico (Fig. 1). The FGB are located $\sim 190 \mathrm{~km}$ south of the Texas-Louisiana border and are coral reefs that have developed on mounds overlaying salt domes at the edge of the continental shelf (Bright et al. 1984). These high-latitude reefs are at the northern limits of environmental conditions that support coral reef development and have a reduced coral diversity, with only 22 of the 60 hermatypic coral species that are found in the wider Caribbean and Atlantic (Bright et al. 1984; Kleypas et al. 1999; Johnston et al. 2017). Since long-term monitoring of benthic cover began in 1989 at both the east and west FGB, coral cover has remained at or above 50\% (Johnston et al. 2017). The remote nature and lack of land-based sources of pollution (e.g., eutrophication, sedimentation etc.) are most often cited as key factors that have allowed FGB to retain high coral cover (Gittings 1998). Additionally, bleaching impacts were minimal up until 2016 and have had no discernable impact on coral cover, which may be because the cooler waters at these sites have only recently begun to exceed thermal thresholds (Johnston et al. 2019). The deep depths $(\geq 16 \mathrm{~m})$ have also been highlighted as likely buffering these reefs from drastic temperature and salinity fluctuations, storm damage, and bleaching (Aronson et al. 2005).

The influence of runoff from the Atchafalaya, Mississippi, and Texas Rivers on the FGB has been debated. Rezak et al. (1990) argued that low-salinity surface waters do not reach the corals at depth and that riverine discharge has a minimal influence on FGB. Dodge and Lang (1983) reported a significant negative correlation between extension rates of Orbicella annularis and Atchafalaya River discharge, but positive correlation with sea temperature. The presence of annual luminescence bands in a core of $O$. faveolata, a presumed indicator of terrigenous runoff (Lough et al. 2002), in conjunction with low-salinity surface waters was used to argue that riverine waters impact FGB on an annual basis (Deslarzes and Lugo-Fernandez 2007). Kealoha et al. (2020a) hypothesized that the combination of high river discharge and upwelling led to hypoxia and a localized, high-mortality event in 2016.

The National Oceanic and Atmospheric Administration (NOAA) implemented the National Coral Reef Monitoring Program (NCRMP) in 2013, which includes in situ climate change and ocean acidification monitoring of US coral
Fig. 1 Map of east Flower Garden Banks (EFGB) in Northwest Gulf of Mexico. Depth contours in meters

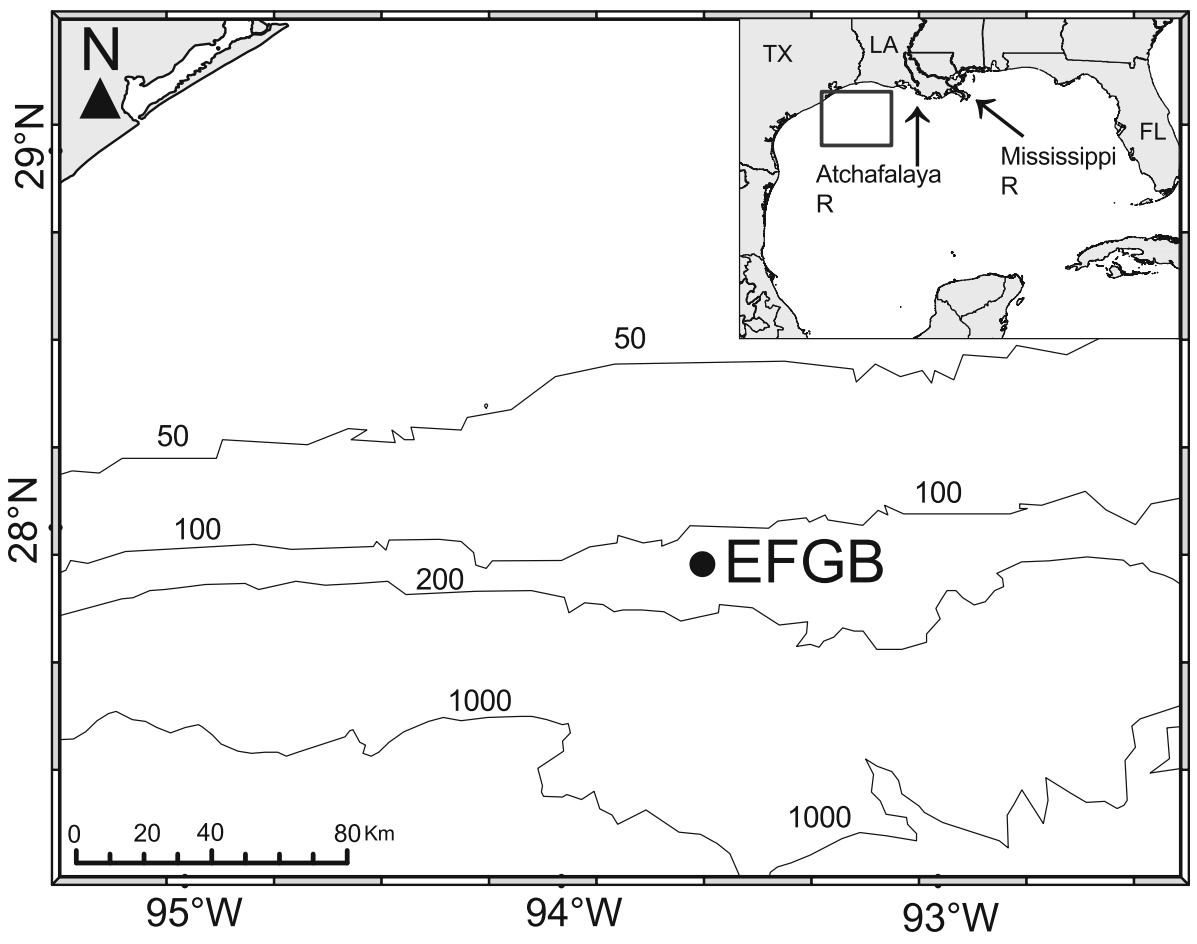


reefs (NOAA Coral Program 2014). A key goal of NCRMP is to take coral cores of the dominant species from key sites to establish long-term historical baselines in coral growth (extension, density, and calcification rate) by which to gauge future change. The FGB was the only US coral reef jurisdiction in the Atlantic Ocean to receive a score of "good" for coral reef condition based on data collected from 2014 to 2018, meaning that indicators of coral reef health did not differ from historical, reference values (NOAA Coral Program 2020). As such, our goal in this study was to measure extension, density, and calcification rates from two of the most abundant species ( $O$. faveolata and $P$. strigosa) at this anomalously healthy site to determine whether there have been any trends with time and linkages with environmental variability, including sea temperature and river discharge.

\section{Materials and methods}

\section{Core collection}

From June 1-4, 2015, cores (5 cm diameter by $30 \mathrm{~cm}$ length) were obtained from ten to 11 colonies of Orbicella faveolata and Pseudodiploria strigosa, respectively, at a mean $\pm \mathrm{SD}$ depth of $19.1 \mathrm{~m} \pm 0.86$ and $20.0 \mathrm{~m} \pm 0.82$ on East Flower Garden Bank near buoy \# 3 (27 54.444 N, $\left.93^{\circ} 35.955 \mathrm{~W}\right)$ using a pneumatic hand drill attached to a SCUBA tank (Fig. 2). Cores were taken from the top of large colonies ( $>1 \mathrm{~m}$ diameter and/or height) and perpendicular to the growth axis. A concrete plug was hammered into the remaining hole to prevent recruitment of competitive or bioeroding organisms that could damage the integrity of the colony.

\section{Coral core analysis}

Coral cores were analyzed as previously described (Groves et al. 2018; Manzello et al. 2018). In brief, cores were scanned with a Siemens SOMATOM Volume Zoom spiral computerized tomography (CT) Scanner at $0.1 \mathrm{~mm}$ resolution. Density measurements were made along the growth axis using Amira software (FEI Visualization Sciences Group, Massachusetts, USA). Density $\left(\mathrm{g} \mathrm{cm}^{-3}\right)$ was determined from grayscale values by linear regression of coral standards of known density. Linear extension $(\mathrm{cm}$ $\mathrm{yr}^{-1}$ ) was determined by measuring the distance between annually repeating high-density (HD) bands using the Coral X-radiograph Densitometry System (CoralXDS) (Helmle et al. 2002). Calcification rates $\left(\mathrm{g} \mathrm{cm}^{-2} \mathrm{yr}^{-1}\right)$ were calculated as the product of density and linear extension.
We followed the method of Rippe et al. (2018) and took the average of three density transects along the growth axis down the length of each core. For P. strigosa, the density transects were drawn within the exothecal space and did not include the high-density corallite wall (Rippe et al. 2018). This method was adopted because it helps standardize the density measurements of brain coral species with complex skeletal architecture. The density and calcification values are lower than would be expected if all the skeletal architecture was considered.

HD bands are deposited during summer and early fall for both O. faveolata and P. strigosa (Hudson et al. 1976; Helmle et al. 2000; Giry et al. 2010). In O. faveolata, a faint band adjacent to the top of core was noticeable in many of the colonies. We interpreted this as incipient 2015 HD band formation and assumed the most recent, fully formed HD band represented summer 2014. For $P$. strigosa, we did not observe the same type of faint band, but rather, noted a well-formed $\mathrm{HD}$ band about $\leq 0.5 \mathrm{~cm}$ down each core. Given the distance from the top of the colony was similar to the annual extension rate in this species, we assumed the well-formed band was deposited in 2014. The data produced when this band was incorporated had very low skeletal density, suggesting that infilling of the skeleton was still taking place. Thus, we utilized the 2013 band as the most recent year of useable data for $P$. strigosa. In summary, the growth records from $P$. strigosa and $O$. faveolata span 1957-2013 and 1970-2014, respectively.

Extension rates, inferred as the distance between repeating $\mathrm{HD}$ bands, do not always represent an exact 12 month calendar year (Lough and Barnes 1990; Carricart-Ganivet 2011). This is because the timing of HD band formation is linked to the calcification rate of the individual coral, such that HD bands form during peak seasonal temperatures, when light levels are high. There is year-toyear variability in the exact timing of temperature peaks; for instance, the warmest month of a year may be July, August, or September on the Mesoamerican Barrier Reef (Carricart-Ganivet 2011). Similarly, the light doses experienced by corals will vary because of local weather and larger-scale climate patterns (Lough and Barnes 1990). Thus, when comparing two different core records side-byside, the timing of band formation can be different. These differences yield annual extension rates that are not a perfect one year of growth and this error is translated to the calcification estimate given that calcification is the product of linear extension and density (Carricart-Ganivet 2011). There can also be significant variability in skeletal density within couplets of HD bands, or intraband variability, and this in turn can lead to variability in the calcification estimate (Rico-Esenaro et al. 2019). Despite the intraband density variability, Rico-Esenaro et al. (2019) found that 
Fig. 2 Photographs of coral colonies at east Flower Garden Bank and computerized tomography (CT) images of cores for (a, b) Pseudodiploria strigosa and (c, d) Orbicella faveolata. CT images illustrate clear annual banding

\section{Pseudodiploria strigosa}
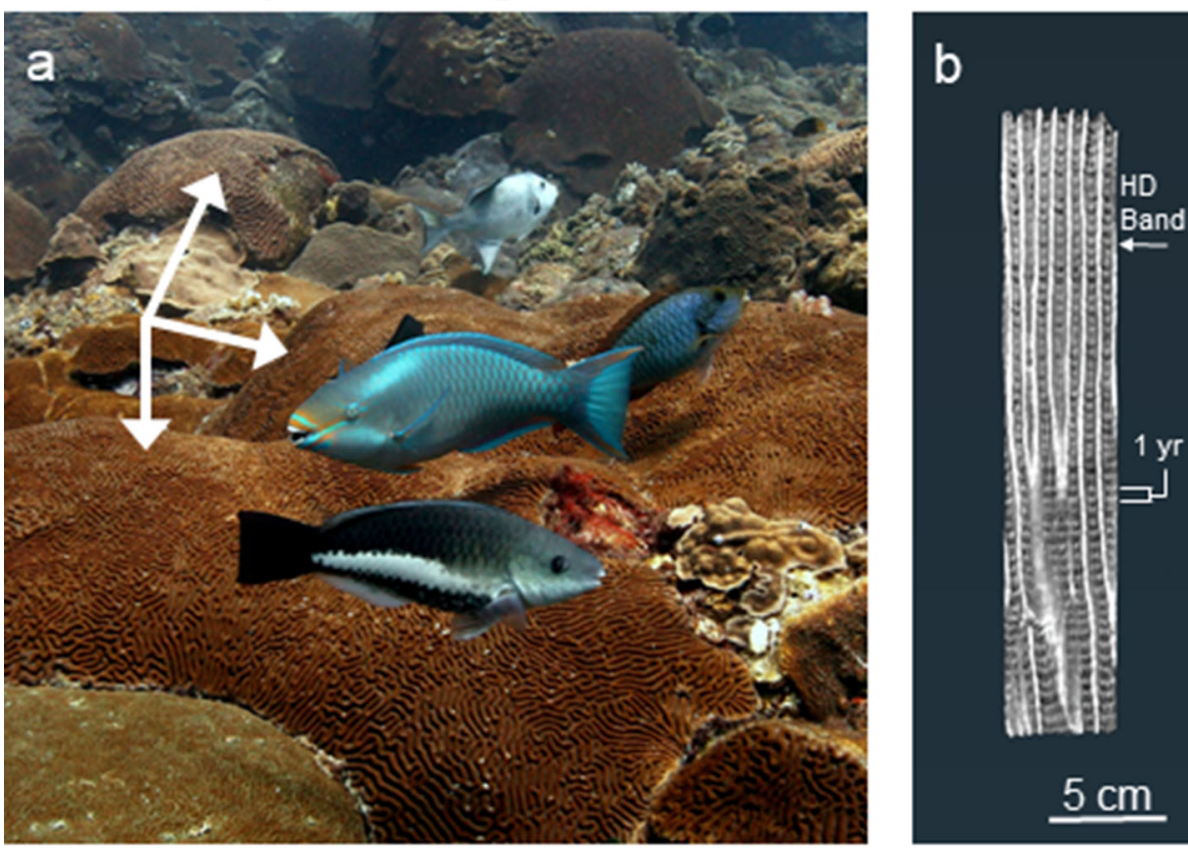

\section{Orbicella faveolata}
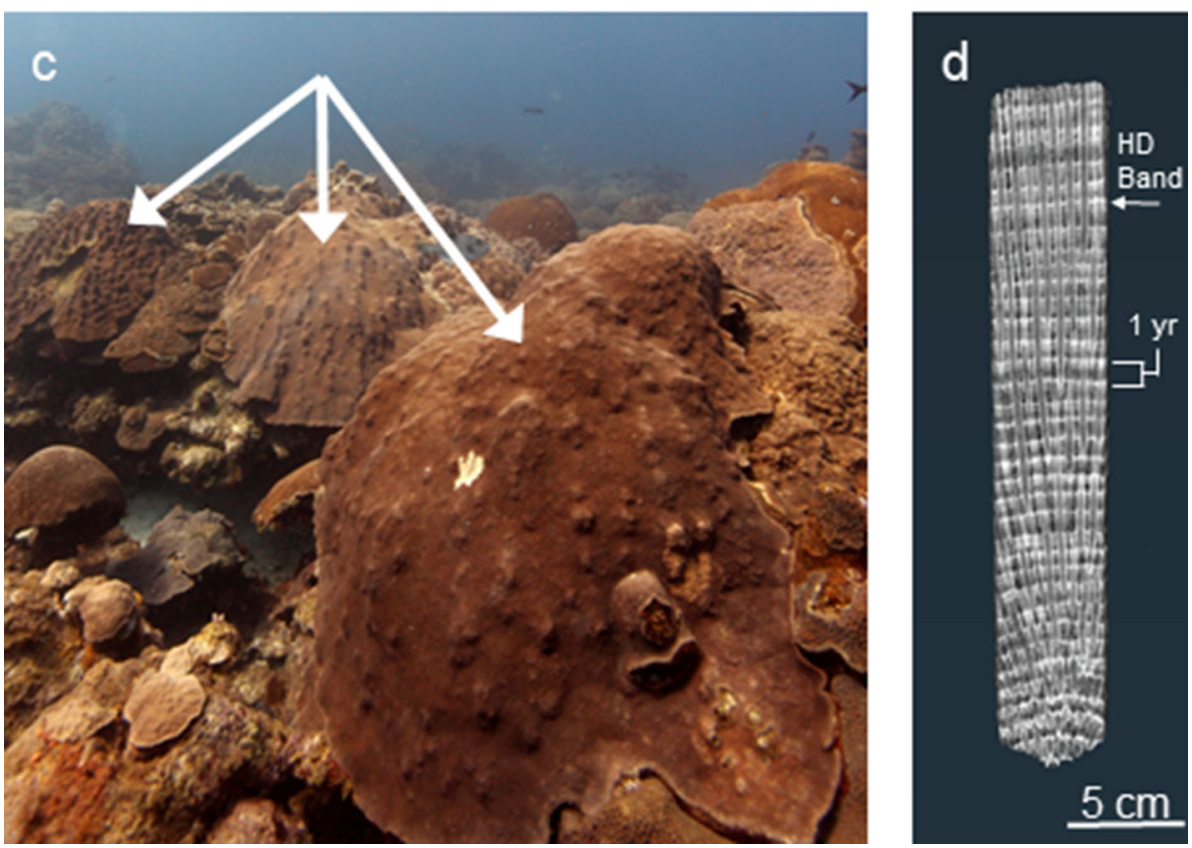

the general trends and patterns were consistent through time in replicate density tracks from the same core. With this in mind, we obtained a large sample size of cores ( $N=10$ per species) in order to minimize the impacts of these uncertainties on our ability to elucidate overall trends and patterns.

\section{Coral growth interpretation}

Annual growth measurements for each core were standardized by dividing each yearly value by the mean of the entire core record (e.g., Dodge and Lang 1983; Rippe et al. 2018). The resultant data are annual fractions (or percentages) of the overall core mean of 1 (or 100\%), such that a value of 1 represents the overall mean; values $<1$ are below average, values $>1$ are above average. This is done 
because each core is of a different length, thus the number of years of data generated from each core are different and all portions of a chronology are not equally weighted. This standardization helps reveal common patterns in growth that could be masked by individual core variations. For example, if you have a core with anomalously high rates (see extension rates of core fgb1505 in this study), this creates an averaging bias in the dataset that artificially impacts the ability to detect trends, especially related to intercore comparisons and responses to environmental stimuli. This is the same type of methodology utilized in dendrochronology, which is why it was adopted for sclerochronology (Dodge and Lang 1983).

To analyze temporal trends in the growth data, we followed the methods of Rippe et al. (2018) and used: (1) linear mixed effect (LME) modeling to determine whether a statistically significant trend with time occurred over the entire record, and (2) generalized additive modeling (GAM) that allowed determination of significant short-term growth dynamics. As in Castillo et al. (2011) and Rippe et al. (2018), the mean standardized values of growth (extension, density, calcification) were considered the units of observation and the individual cores were treated as sampling units with random effects. This modeling approach addresses the hierarchical nature of the data and inherent temporal autocorrelation. Several models were tested to determine the best fit of the data and Akaike Information Criteria (AIC) was used to pick the best model. The models tested included: (1) simple linear regression, (2) random intercepts with no predictors, (3) a random intercepts model with time as a predictor, and (4) a random slopes and intercepts model whereby the intercept and slope were allowed to be random (Castillo et al. 2011). The residual correlation structure of the individual cores was described with an autoregressive moving-average model of order (p, q). The models with the best fits are shown in Table S1. In Table S2, we show the full LME selection process, as an example, for $P$. strigosa. The LME selection process was the same for $O$. faveolata and both species combined.

GAM modeling is well suited to capture dynamic fluctuations in growth that are nested within the long-term trend revealed through the LME, allowing quantification of significantly increasing or decreasing time periods of growth. An adaptive smoothing spline was incorporated to treat year as a fixed effect predictor and the individual cores as random effects. The smoothing basis was selected sensu Wood (2017), where $k$ is increased $(k=10,15,20$ etc.) until the effective degrees of freedom stabilize at a value lower than $k-1$. A $k=25$ was used as in Rippe et al. (2018). The intervals of significant change were computed using the first derivative of the fitted spline (Bennion et al. 2015). The finite difference approximation of the first derivative is determined at fixed points with a 95\% confidence interval, and when the confidence interval excludes zero (i.e., zero slope), it is concluded that significant change of growth occurred. The intervals of significant change are indicated on the GAM plots as segments for increases and red segments for decreases. The nlme package in $\mathrm{R}$ was used for LMEs, whereas the $m g c v$ package was used for GAMs (R Core Team 2019).

\section{River discharge and sea surface temperature (SST)}

River discharge data for the Mississippi and Atchafalaya Rivers were sourced from river gauges maintained by the US Army Corp of Engineers (US Army Corp of Engineers 2020). The daily computed flow values are based on and related to corresponding stage values read at each gauge. The river discharge (flow) data were converted from cubic feet per second (CFS) to $\mathrm{m}^{-3} \mathrm{~s}^{-1}$, and the daily values were summed to get a yearly rate. Sea surface temperature (SST) data from 1957 to 2014 were obtained from the HadISST 1.1 database (Rayner et al. 2003). It should be noted that satellite and modeled SSTs may not perfectly predict thermal conditions, including thermal stress at depth as a result of physical processes like thermocline shoaling or wind-driven mixing (Castillo and Lima 2010; Schramek et al. 2018; Wyatt et al. 2020). We utilized the HadISST dataset because it was continuous and complete over the duration of our core records, and reflects largescale trends and patterns. In situ temperature data measurements from the FGB extend back to the 1990s, but are discontinuous and of limited utility to discerning patterns over the entirety of our core records. Given that thermal variability increases with depth and the FGB is a deep site ( $>16 \mathrm{~m}$ ), future work is needed to compare in situ temperature data at depth with satellite SST sources to quantify biases and uncertainties (e.g., Castillo and Lima 2010). This will be important in a warming ocean for accurate monitoring and predictions of coral bleaching at FGB.

Four different metrics of annual river outflow were assessed: (1) Atchafalaya River discharge, (2) Mississippi River discharge, (3) Mississippi plus Atchafalaya River discharge, and (4) sum of the current and prior year's Atchafalaya River discharge. Discharge from the Atchafalaya and Mississippi Rivers both individually (metric 1, 2) and combined (metric 3) was compared to the coral growth data. Following the suggestion of Deslarzes and Lugo-Fernandez (2007), we computed an additional measure of Atchafalaya River discharge by summing the current and previous year together (metric 4). This was done because the complicated hydrodynamics of the TexasLouisiana shelf often result in the entrainment of river runoff such that there is a mix of the current and prior years outflow that can reach FGB during summer (Deslarzes and 
Lugo-Fernandez 2007). We labeled the sum of the current and prior year's Atchafalaya discharge as 'atchDes.'

To determine whether any of the environmental variables correlated with annual means of standardized extension, density, and calcification for each species individually, and both pooled, we used Pearson correlation (Spearman if assumptions of homoscedasticity and normality not met). When more than one variable was correlated with a growth parameter, multiple linear regression was used with function $l m$ in $R$ (R Core Team 2019). The assumptions of normality and equal variances were met for regression analysis. Statistical analysis of environmental variables against coral growth parameters was done in $R$ (R Core Team 2019).

\section{Results}

\section{Growth variability within and between species}

The core-averaged values of extension, density, and calcification were significantly greater in $O$. faveolata than $P$. strigosa (Kruskal-Wallis tests, $p<0.01$ ) (Table 1). There was significant variation within growth parameters for each species, due to a few cores with high extension rates (oneway ANOVA, $p<0.001)$. Ten of the $11 P$. strigosa cores exhibited mean extension rates that ranged from 0.43 to $0.62 \mathrm{~cm} \mathrm{yr}^{-1}$, but core fgb1505 yielded a mean $\pm \mathrm{SE}$ extension rate of $0.95 \pm 0.02 \mathrm{~cm} \mathrm{yr}^{-1}$ (Table S3). The mean calcification rate from this core $\left(0.75 \mathrm{~g} \mathrm{~cm}^{-2} \mathrm{yr}^{-1}\right)$, however, was similar to two other cores (fgb1509, fgb1536). This comparable calcification rate is because the mean density of core fgb1505 $\left(0.80 \mathrm{~g} \mathrm{~cm}^{-3}\right)$ was the lowest of all cores from both species, and calcification is the product of extension and density.

Calcification rates for $O$. faveolata were similar between cores except for two colonies. Core fgb1495 yielded the highest calcification rate of all cores $\left(1.32 \pm 0.04 \mathrm{~g} \mathrm{~cm}^{-2} \mathrm{yr}^{-1}\right)$, whereas core fgb1499 $\left(0.69 \pm 0.02 \mathrm{~g} \mathrm{~cm}^{-2} \mathrm{yr}^{-1}\right)$ was lowest (Tukey post hoc tests, $p<0.05$ ). The remaining eight $O$. faveolata cores had similar mean calcification rates, ranging from 0.93 to $1.03 \mathrm{~g} \mathrm{~cm}^{-2} \mathrm{yr}^{-1}$ (Table S3).

Extension, density, and calcification rates did not exhibit a clear, consistent response during known bleaching years (Fig. S1). Overall, O. faveolata exhibited increased extension and calcification with each successive bleaching event after 1995, whereas the opposite occurred for $P$. strigosa. None of the growth parameters was significantly different during any bleaching year for $P$. strigosa (Oneway ANOVAs). For $O$. faveolata, the last bleaching year (2010) had significantly higher extension and calcification than the 1995 event (Tukey post hoc tests, $p<0.05$ ).

\section{Growth through time}

Linear mixed effects modeling revealed a significant increase in standardized extension and calcification for $P$. strigosa from 1957 to 2013 and O. faveolata from 1970 to 2014, as well as for both species combined during overlapping years (1970-2013) (Fig. 3). Coral skeletal density did not exhibit any significant trends with time (Fig. S2, Table S1).

Generalized additive modeling (GAM) showed that $P$. strigosa exhibited growth anomalies coincident with periods of high discharge of the Atchafalaya River, whereas $O$. faveolata only exhibited periods of significant change coincident with documented bleaching events (Fig. 4, Table 2). When data were pooled, the influence of both bleaching and Atchafalaya discharge was highlighted in the GAM. P. strigosa exhibited more variability than $O$. faveolata, as $O$. faveolata extension and calcification declined slightly from 1970 to the mid-1990s, but then increased thereafter. Bleaching impacts were inferred during periods of recovery following a documented event, rather than a significant decline associated with the event. For instance, there was a significant increase in $O$. faveolata calcification from 2007 to 2010, which was in between documented bleaching in 2005 and 2010, yet there were no significant declines in extension or calcification associated with either of those bleaching events (Fig. 4). Rather, there was a significant increase in calcification during recovery from the 2005 event.

\section{Correlation of coral growth with environmental variables}

Discharge from the Atchafalaya River, represented as the sum of the current and previous year's discharge sensu Deslarzes and Lugo-Fernandez (2007), negatively correlated with extension and calcification for $P$. strigosa and both species pooled (Fig. 5, Table 3). Up to the year 2000,
Table 1 Summary of growth parameters for Pseudodiploria strigosa and Orbicella faveolata

\begin{tabular}{lllll}
\hline Species & $\mathrm{N}$ & Extension $\left(\mathrm{cm} \mathrm{yr}^{-1}\right)$ & Density $\left(\mathrm{g} \mathrm{cm}^{-3} \mathrm{yr}^{-1}\right)$ & Calcification $\left(\mathrm{g} \mathrm{cm}^{-2} \mathrm{yr}^{-1}\right)$ \\
\hline P. strigosa & 11 & $0.57(0.04)$ & $1.16(0.04)$ & $0.65(0.02)$ \\
O. faveolata & 10 & $0.71(0.04)$ & $1.42(0.03)$ & $0.99(0.05)$ \\
\hline
\end{tabular}

Values are the mean $( \pm \mathrm{SE})$ of all core means. $N$ is number of cores 


\section{Pseudodiploria strigosa}
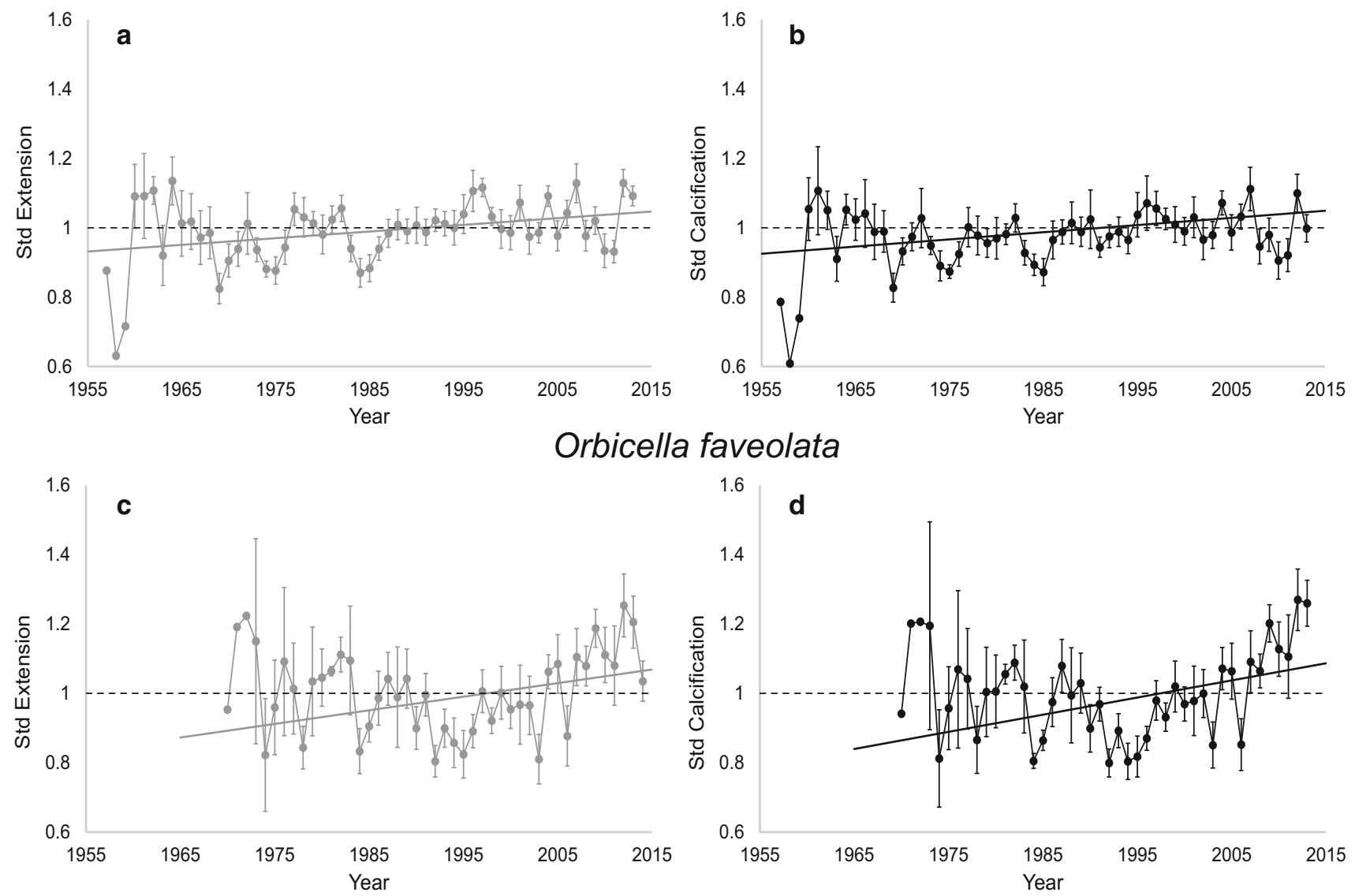

\section{Both Species}

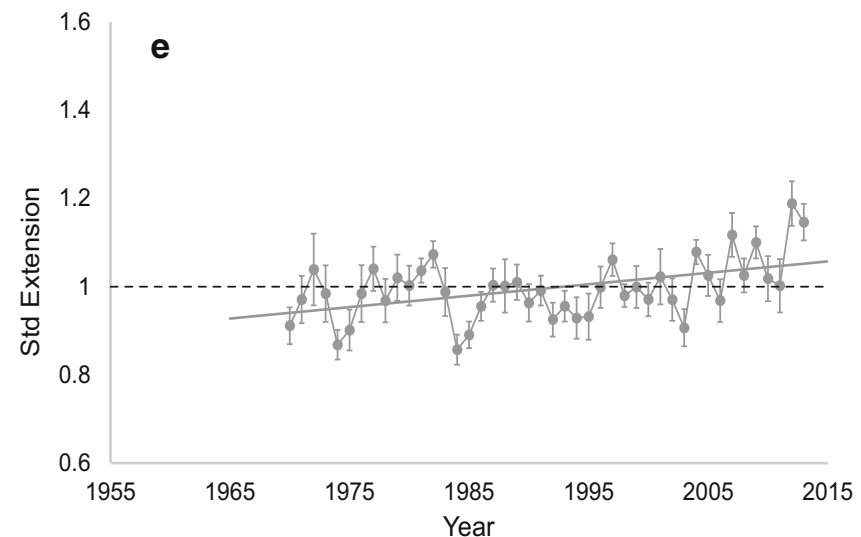

Fig. 3 Standardized extension and calcification for Pseudodiploria strigosa from 1957 to 2013 (a, b), Orbicella faveolata from 1970 to 2014 (c, d), and both species pooled from 1970 to 2013 (e, f). Individual points are means \pm SE. Points without error bars represent a single core. Trend lines estimated using linear mixed effects models

calcification of both species of coral was nearly a mirror image of Atchafalaya discharge (Fig. 5a). Maximum monthly SST was positively correlated with extension and calcification of both species pooled (Fig. 5b), while minimum monthly SST was positively correlated with density

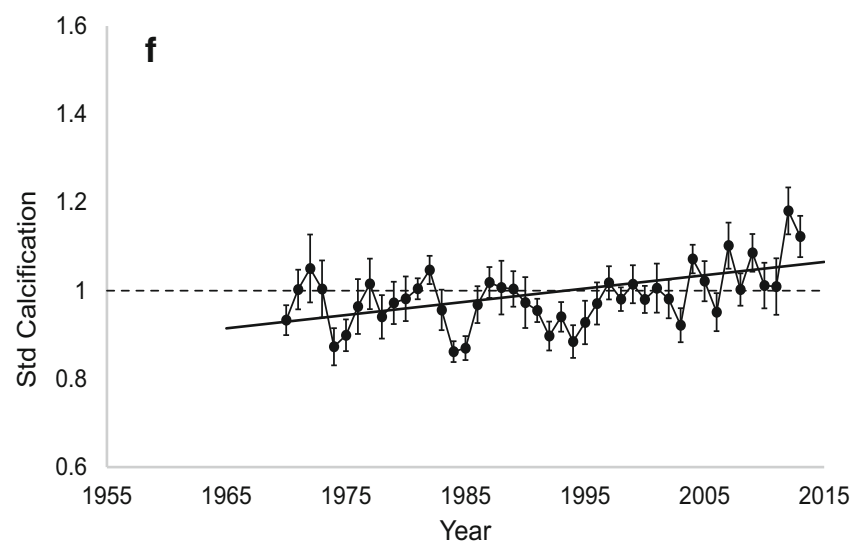

as described. The dashed line represents the mean of the core records, such that annual values above the dashed line represent years of growth greater than the overall average, whereas those below represent years below average

in P. strigosa and both species pooled. None of the environmental variables examined was correlated with any of the growth parameters for $O$. faveolata.

A multiple regression analysis incorporating Atchafalaya discharge and max SST as predictors of extension 

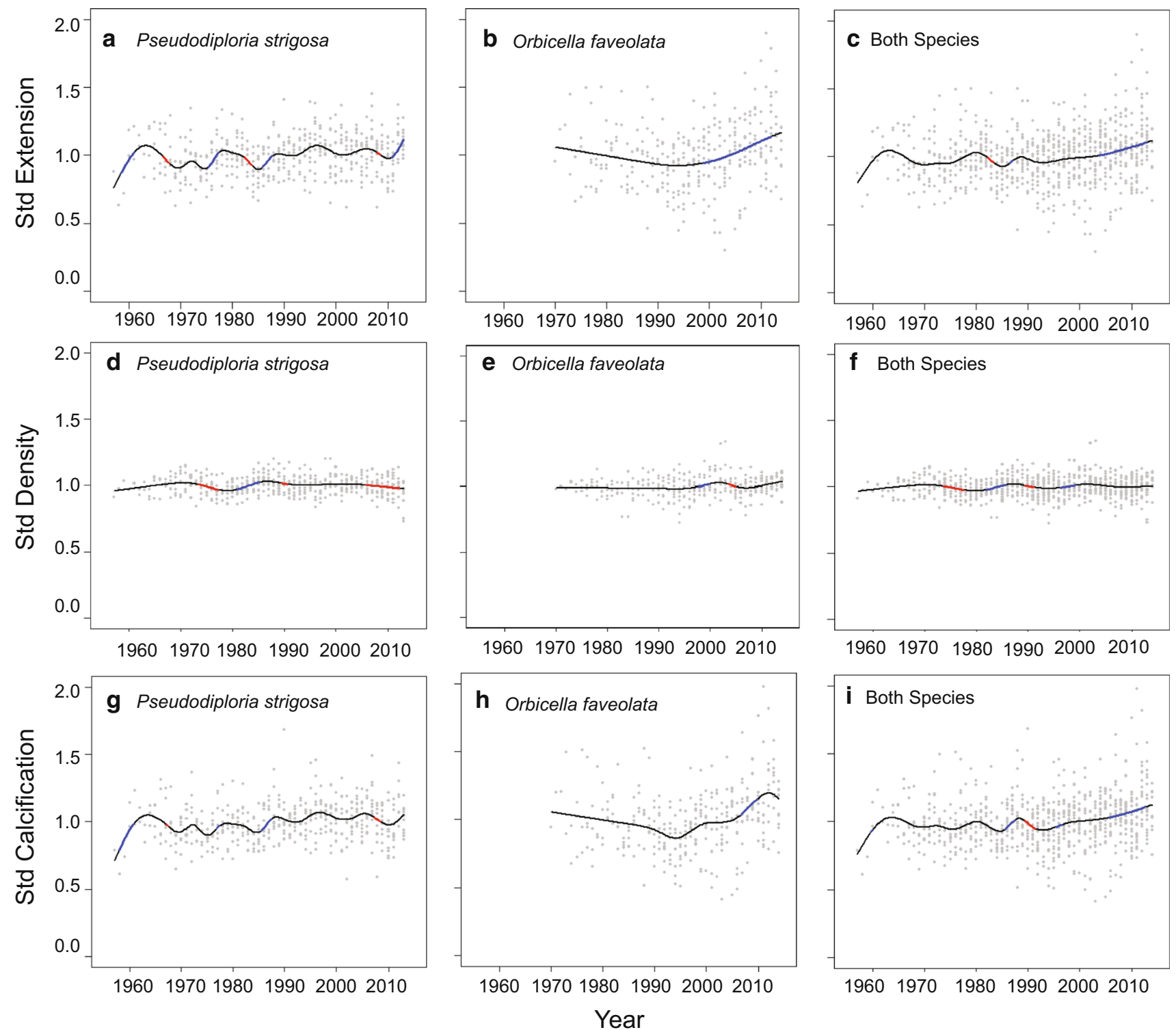

Fig. 4 Generalized additive model predictions for standardized extension, density, and calcification for Pseudodiploria strigosa (a, d, g), Orbicella faveolata (b, e, h), and both species pooled $(\mathbf{c}, \mathbf{f}, \mathbf{i})$.

and calcification for the pooled data provided the best fit, as opposed to individual linear regression of the two individual variables (Table 4). There was no interaction between Atchafalaya discharge and max SST, and the two variables were not correlated. The two equations that predict standardized extension and calcification as a function of Atchafalaya discharge and maximum SST are:

Std Extension $=-0.493-\left(3.29 \times 10^{8} \times\right.$ atchDes $)$ $+(0.055 \times$ MaxSST $)$.

Std Calcification $=-0.3-\left(3.27 \times 10^{8} \times\right.$ atchDes $)$ $+(0.0482 \times$ MaxSST $)$.

The only trend in the environmental data was in maximum SST, which displayed a significant increase from
Blue and red segments represent portions of the curve that are significantly increasing and decreasing, respectively

1957-2014, spanning all data (linear regression: $r^{2}=0.12$, $F=7.7, p<0.01)$ and for the period when both species data overlap, 1970-2013 $\left(r^{2}=0.18, F=9.5, p<0.01\right)$. The significant increase in calcification for both species tracked the trend in maximum SST (Fig. 5b).

\section{Discussion}

The extension and calcification rates of $O$. faveolata and $P$. strigosa at east FGB have both increased significantly from 1970 to 2014 and 1957-2014, respectively. This increase in coral growth can be attributed to the significant warming 
Table 2 Years of significantly increasing and decreasing standardized (Std) extension, density, and calcification for Pseudodiploria strigosa and Orbicella faveolata from East Flower Garden Banks

\begin{tabular}{|c|c|c|c|}
\hline Species & Growth parameter & Increasing years & Decreasing years \\
\hline \multirow[t]{10}{*}{ P. strigosa } & \multirow[t]{4}{*}{ Std extension } & 1959-1961 (C) & 1967-1968 (D) \\
\hline & & 1976-1978 (A) & 1983-1984 (D) \\
\hline & & 1986-1988 (A) & 2009-2009 (D) \\
\hline & & 2012-2014 (B $\left.{ }^{+}\right)$ & \\
\hline & \multirow[t]{3}{*}{ Std density } & \multirow[t]{3}{*}{ 1982-1986 (D) } & 1974-1978 (D) \\
\hline & & & 1990-1991 (D) \\
\hline & & & 2007-2013 (?) \\
\hline & \multirow[t]{3}{*}{ Std calcification } & 1958-1961 (C) & 1968-1968 (D) \\
\hline & & 1977-1978 (A) & 2008-2009 (D) \\
\hline & & 1986-1988 (A) & \\
\hline \multirow[t]{3}{*}{ O. faveolata } & Std extension & 2000-2013 (B $\left.\mathbf{B}^{+}\right)$ & \\
\hline & Std density & 1998-2001 (B) & 2004-2006 (B) \\
\hline & Std calcification & 2008-2011 (B $\left.\mathbf{B}^{+}\right)$ & \\
\hline \multirow[t]{8}{*}{ Both species } & \multirow[t]{2}{*}{ Std extension } & 1987-1988 (A) & 1983-1984 (D) \\
\hline & & 2005-2014 (B $\left.\mathbf{B}^{+}\right)$ & \\
\hline & \multirow[t]{2}{*}{ Std density } & 1983-1986 (D) & 1974-1978 (D) \\
\hline & & 1997-2000 (B) & 1990-1992 (D) \\
\hline & \multirow[t]{4}{*}{ Std calcification } & 1960-1960 (C) & 1990-1992 (D) \\
\hline & & 1986-1988 (A) & \\
\hline & & 1996-1997 (?) & \\
\hline & & $2007-2014\left(\mathbf{B}^{+}\right)$ & \\
\hline
\end{tabular}

Significance denoted from GAM analysis. Letters in parentheses denote events associated with periods of change and are defined in footnotes

A, Recovery periods associated with declines in Atchafalaya River discharge after periods of high discharge

$\mathbf{B}^{+}$, Recovery periods after high temperatures and reported bleaching. Note: declines in discharge also occurred after 1998, 2005, and 2010

B, Growth anomalies associated with bleaching and/or periods of elevated max SST (e.g., 1997/1998). Note: Hurricane Rita occurred in 2005 as well

C, Recovery in growth following sharp decline in 1957 reported by Hudson and Robbin (1981) and Dodge and Lang (1983)

D, Growth declines/anomalies associated with periods of high Atchafalaya discharge (1973-75, 1983-85, 1990-91, 1994, 1998, 2009-11). Includes period from 1964 to 1970 that saw a rapid increase in Atchafalaya discharge

?, Growth anomalies that are not associated with a known event or environmental factor trend documented here as well as in the wider Caribbean (Muniz-Castillo et al. 2019). A similar pattern of increased coral growth associated with warming has been previously documented on the Great Barrier Reef (GBR) and Western Australian coral reefs (Lough and Barnes 2000; Cooper et al. 2012). On the GBR, calcification increased over the 20th century and then rapidly declined coincident with the start of mass bleaching on the GBR in 1998 (De'ath et al. 2009). Stimulation of calcification from warming does appear to be most pronounced in high-latitude reefs that experience cooler temperatures, as suggested by Tanzil et al. (2013). As Cooper et al. (2012) discussed, this is contrary to the idea that ocean acidification (OA) impacts will occur first, and most severely at high latitudes due to lower aragonite saturation states. They suggested that the rate of change of the thermal environment appears to be the overall dominant driver of recent changes in coral growth rates, although newer evidence suggests that corals may be experiencing the impacts of $\mathrm{OA}$ as a decline in skeletal density (Mollica et al. 2018; Guo et al. 2020).

The rate and magnitude of $\mathrm{OA}$ at the FGB are unknown over the period covered by our cores. The threat of OA in the northwest Gulf of Mexico is poorly understood because seawater carbonate chemistry is influenced by the interplay of varying river discharge and the complex hydrodynamics of this region (Kealoha et al. 2020b). Over the 10-yr period from 2007 to 2017, Hu et al. (2018) reported a rate of OA at FGB that was greater than what has been measured in the 
Fig. 5 Standardized

calcification (black line) of both species pooled plotted against

(a) Atchafalaya River discharge (brown line) and (b) maximum monthly sea surface temperature (SST, red line). Standardized density (black line) of both species plotted against minimum monthly SST (blue line) (c). Trend line in (b) for calcification (black trend line) estimated using linear mixed effects models as described, whereas trend line for SST is simple linear regression (red trend line). Individual points are means \pm SE for growth parameters
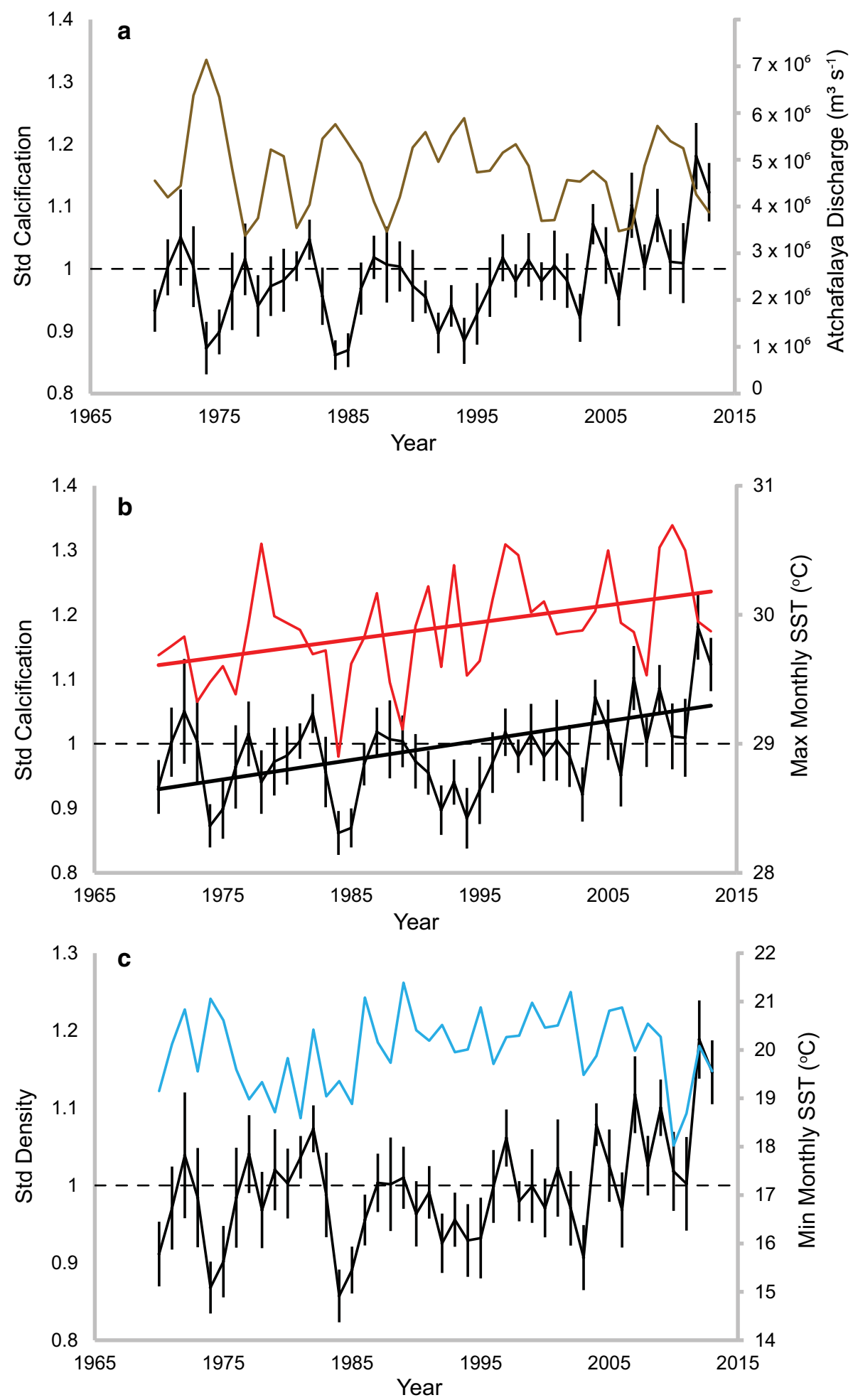

open ocean. However, just to the east in the central regions of the open-ocean and coastal portion of the Gulf of Mexico, there has been no long-term trend in surface $\mathrm{pCO}_{2}$, SST, or salinity (Kealoha et al. 2020b). The impact of runoff from the Mississippi and Atchafalaya Rivers can effectively erase any OA signal because runoff impacts surface productivity, as well as directly modifies seawater chemistry, both of which introduce variability that makes a long-term OA signal difficult to detect.

$\mathrm{OA}$ is expected to reduce coral calcification and/or cause a decline in skeletal density (Chan and Connolly 2013; Mollica et al. 2018; Guo et al. 2020). There were no 
Table $3 \mathrm{P}$ values of correlations between average growth parameters for Pseudodiploria strigosa, Orbicella faveolata, and both species with river discharge and sea surface temperature data

\begin{tabular}{|c|c|c|c|c|c|c|c|c|}
\hline Species & Growth parameter & Atchafalaya & Mississippi & Both rivers & AtchDes & Min SST & Mean SST & Max SST \\
\hline \multirow[t]{3}{*}{ P. strigosa } & Std Ext & 0.20 & 0.73 & 0.51 & $r=-0.32 *$ & 0.65 & 0.38 & 0.22 \\
\hline & Std Dens & 0.96 & 0.53 & 0.66 & 0.20 & $r=0.29 *$ & 0.30 & 0.10 \\
\hline & Std Calc & 0.17 & 0.47 & 0.34 & $r=-0.29 *$ & 0.38 & 0.30 & 0.60 \\
\hline \multirow[t]{3}{*}{ O. faveolata } & Std Ext & 0.75 & 0.59 & 0.63 & 0.22 & 0.39 & 0.86 & 0.35 \\
\hline & Std Dens & 0.45 & 0.33 & 0.36 & 0.09 & 0.89 & 0.67 & 0.20 \\
\hline & Std Calc & 0.62 & 0.44 & 0.49 & 0.13 & 0.38 & 0.94 & 0.21 \\
\hline \multirow[t]{3}{*}{ Both spp. } & Std Ext & 0.13 & 0.33 & 0.25 & $r=-0.44 * *$ & 0.75 & 0.34 & $r=0.36^{*}$ \\
\hline & Std Dens & 0.47 & 0.20 & 0.27 & 0.77 & $\mathrm{r}=0.34^{*}$ & 0.16 & 0.47 \\
\hline & Std Calc & 0.09 & 0.17 & 0.14 & $\mathrm{r}=-0.45^{* *}$ & 0.88 & 0.20 & $r=0.33^{*}$ \\
\hline
\end{tabular}

AtchDes represents the sum of the current and previous year discharge from the Atchafalaya River sensu Deslarzes and Lugo-Fernandez (2007). Correlation coefficient included for significant relationships: $* p<0.05$; $* *<0.01 ; * * *<0.001 . p$ values of correlations that were not significant at the alpha $=0.05$ level are included to show other possible trends for future study

Table 4 Comparison of regression statistics for simple linear versus multiple regression of both coral species' extension and calcification as a function of Atchafalaya River discharge and maximum SST

\begin{tabular}{lllrrr}
\hline Growth Parameter & Environmental variable & $r^{2}$ & \multicolumn{1}{c}{ A } & $p$-value & AIC \\
\hline Std Extension & AtchDes & 0.20 & 10.3 & $<0.01$ & -115.2 \\
& Max SST & 0.13 & 6.1 & $<0.05$ & -111.5 \\
& AtchDes + Max SST & $\mathbf{0 . 2 6}$ & $\mathbf{8 . 6}$ & $<\mathbf{0 . 0 0 1}$ & $-\mathbf{1 1 9 . 0}$ \\
Std Calcification & Atch Des & 0.21 & 10.9 & $<0.01$ & -118.8 \\
& Max SST & 0.11 & 5.1 & $<0.05$ & -113.7 \\
& AtchDes + Max SST & $\mathbf{0 . 2 5}$ & $\mathbf{8 . 3}$ & $<\mathbf{0 . 0 0 1}$ & $-\mathbf{1 2 1 . 5}$
\end{tabular}

AtchDes represents the sum of the current and previous year discharge from the Atchafalaya River sensu Deslarzes and Lugo-Fernandez (2007). The $r^{2}$ value for the multiple regressions represents adjusted $r^{2}$. Bold face shows best data fit. Multiple regression done with $R$ using the function $1 \mathrm{~m}$ (R Core Studio 2019) declines in long-term calcification rates or skeletal density of the corals analyzed from FGB; calcification rates have increased in both coral species, whereas skeletal density did not exhibit any trends (Fig. S2). There was a significant decline in density, however, during the last seven years for $P$. strigosa that could not be attributed to river runoff or bleaching (Table 2). This decline in density within the past decade could be the start of a longer-term decline like that found in massive Porites on the GBR and in three different species of coral on the Florida Reef Tract, including the two studied herein (Helmle et al. 2011; Rippe et al. 2018; Guo et al. 2020). Indeed, Hu et al. (2018) showed that the rate of OA at FGB was higher than the rate in the open ocean from 2007 to 2017, which overlaps with the significant decline in skeletal density of $P$. strigosa (Table 2). Future coring studies are necessary to determine whether this decline in density has continued and if it is related to in situ changes in seawater carbonate chemistry.

The data presented here provide evidence that discharge from the Atchafalaya River impacts FGB corals and is a major control on coral growth, as previously suggested (Dodge and Lang 1983; Deslarzes and Lugo-Fernandez
2007). Our results provide further evidence of the importance of Atchafalaya runoff to FGB because we report data for an additional species of coral ( $P$. strigosa), as well as the first measurements of skeletal density and calcification. Deslarzes and Lugo-Fernandez (2007) observed luminescent bands in their core from FGB, but the mechanism behind incorporation of these bands is not fully understood. Luminescent banding is normally most prevalent in nearshore corals that are exposed to high levels of runoff with increased nutrients, sedimentation, and turbidity; thus, it was thought banding was associated with incorporation of terrigenous humic substances into the skeleton (Isdale 1984; Boto and Isdale 1985; Lough et al. 2002). However, it was later observed that corals that were not exposed to runoff can also have luminescent lines, which led to a revised explanation for this phenomenon. Barnes and Taylor (2001) posit that it is the $\mathrm{CaCO}_{3}$ skeleton that luminesces and the intensity is controlled by the skeletal structure. They suggest that a change in skeletal architecture occurs because of reduced calcification during periods of depressed salinity. This explanation is problematic for FGB because low-salinity waters are usually only found in 
a thin surface layer and rarely, if ever, impact the corals at depth (Rezak et al. 1990; Deszlarzes and Lugo-Fernandez 2007). Furthermore, by the time riverine waters impinge on the FGB they are low in chlorophyll $a$ and depleted in nutrients, such that they can no longer support phytoplankton blooms; thus, direct incorporation of terrigenous materials seems unlikely (Deslarzes and Lugo-Fernandez 2007).

The presence of luminescent banding in FGB corals is enigmatic given that none of the mechanisms proposed seems probable for this site. An explanation for luminescent bands in FGB corals may have been elucidated by a presumed recent hypoxia event that led to localized, yet significant coral mortality in 2016 at FGB, with up to $80 \%$ mortality reported in some areas (Kealoha et al. 2020a). These authors proposed that hypoxia occurred because high riverine discharge led to a low salinity, turbid surface layer that migrated over FGB, blocking sunlight, reducing photosynthesis, and leading to increased respiration of organic matter. Coincident with this event, it is argued that there was an intrusion of deep, dense water that was low in oxygen and $\mathrm{pH}$, but high in ammonium and dissolved inorganic carbon, that settled into pockets of the reef causing a strongly stratified bottom layer that prevented reoxygenation from the overlying water column. The presence of a microbial consortium indicative of a deepwater community was observed in shallow water, providing further evidence that upwelling does occur at FGB, as has been shown previously (Teague et al. 2013). Riverderived, turbid surface waters would reduce the light levels reaching the corals and likely lead to depressed calcification, as has been suggested (Dodge and Lang 1983), whereas upwelled waters that are high in nutrients could lead to organic matter retention within the skeleton. Future research is required to determine the frequency of upwelling at FGB, and if upwelling regularly co-occurs with periods of high river discharge, or if the two processes are independent of one another. If upwelling events do occur regularly and coincide with the impingement of turbid surface layers, then both of these processes could be involved and control the intensity of luminescent banding in FGB corals.

The environmental controls on coral skeletal density are not well understood and can be species-specific. The positive relationship we observed between skeletal density and minimum SST for P. strigosa and both species combined (Table 3, Fig. 5c) is similar to the positive relationship between skeletal density and SST (average and maximum) observed for Orbicella annularis in the wider Atlantic (Carricart-Ganivet 2004). Lough and Barnes (2000) reported a negative relationship between annual average SST and skeletal density in massive Porites from the Pacific. These differences are related to differing growth strategies, such that massive Porites invests any increases in calcification resources to increased extension, whereas Orbicella spp. put resources toward increased density (Carricart-Ganivet 2011). Our data suggest that the growth strategy for $P$. strigosa is similar to that of $O$. annularis, as it was hypothesized by Carricart-Ganivet (2011). Colder, upwelled waters that are high in nutrients and have low $\mathrm{pH}$ can lead to depressed skeletal density (Manzello et al. 2014). If we assume that upwelled waters reach the surface during winter months, then minimum monthly SST could be a proxy for upwelling intensity. Thus, warmer winters (higher minimum SSTs) would correspond to less upwelling and denser skeletons. Conversely, cooler winters (lower minimum SSTs) may reflect greater upwelling and less dense skeletons. The hypoxia event in 2016 that was tied to upwelling and river discharge would be unlikely to occur in winter due to high winds and wave heights leading to enhanced mixing at depth. Future work is required to better understand if there are additional mechanisms behind the correlation between density and minimum SST that we observed. The interaction between upwelling and thermal stress on coral calcification can be complex and species-specific, requiring future study (e.g., Courtney et al. 2020).

Prior coring studies of the congeneric species, $O$. annularis, from FGB yielded similar, yet slightly higher extension rates. Hudson and Robbin (1981) measured a mean extension rate from 12 cores of $8.9 \mathrm{~mm} \mathrm{yr}^{-1}$ from 1907 to 1957 that then declined sharply in 1957 and remained depressed at $7.2 \mathrm{~mm} \mathrm{yr}^{-1}$ from 1957 to 1979 . Additional coring later found a mean extension from four O. annularis cores of $6.6 \mathrm{~mm} \mathrm{yr}^{-1}$ from 1910 to 1989 , noting the same decline in growth in 1957 as Hudson and Robbin (1981) and increased variability from 1957 to 1980 (Gittings et al. 1992). Lastly, Bright et al. (1984) reported a mean extension rate of $8 \mathrm{~mm} \mathrm{yr}^{-1}$ for one $O$. annularis core from 1964 to 1980 and $5 \mathrm{~mm} \mathrm{yr}^{-1}$ for one core of $P$. strigosa over the same time frame. Our overall mean extension rate of $7.1 \mathrm{~mm} \mathrm{yr}^{-1}$ for $O$. faveolata is nearly the same as what was observed in the $O$. annularis cores after 1957. The $P$. strigosa extension rate of $5 \mathrm{~mm} \mathrm{yr}^{-1}$ is well within the range of core means we observed for this species (Table S3). The mean extension and calcification rates of $P$. strigosa at FGB were higher than the mean values observed across seven reef sites in the Florida Keys (Florida extension: $3.8-5.5 \mathrm{~mm} \mathrm{yr}^{-1}$; calcification, $0.46-0.64 \mathrm{~g} \mathrm{~cm}^{-2} \mathrm{yr}^{-1}$ ), while skeletal densities between FGB and Florida were comparable (Florida density: 1.05-1.26 $\mathrm{g} \mathrm{cm}^{-3} \mathrm{yr}^{-1}$, Rippe et al. 2018). The greater extension and calcification rates at FGB were unexpected given the greater depths of the sampled FGB corals $(19-20 \mathrm{~m})$ than those sampled in the Florida Keys (3-7.5 m). The higher rates in the FGB may reflect the 
increasing trend in extension and calcification rates that we documented herein, as average rates for P. strigosa were higher than the prior FGB coring study. Conversely, extension and calcification of $P$. strigosa have remained stable in the Florida Keys over the past 20-60 years (Rippe et al. 2018). The sharp decline in extension in 1957 was apparent in our one $P$. strigosa core that went back that far, verifying that there was a multispecies decline in extension and calcification during this time. Cold-water stress drove the large depression in growth in 1957 (Dodge and Lang 1983).

The core data from FGB differ from other studies that have shown a decline in calcification over time, generally in concert with the timing of overall coral reef decline. Declines in coral growth attributed to ocean warming have been reported in the Red Sea, Belize, Mexico, and southeast Asia (Cantin et al. 2010; Castillo et al. 2011, 2012; Carricart-Ganivet et al. 2012; Tanzil et al. 2013). In these studies, chronic warming slowed growth as opposed to acute thermal stress and coral bleaching. De'ath et al. (2009) argued that thermal stress and bleaching, plus possibly OA, were likely responsible for the decline in calcification of massive Porites on the GBR from 1990 to 2005, which was unprecedented over the past $400 \mathrm{yrs}$. It has been long understood that coral bleaching leads to depressed calcification (Goreau and Macfarlane 1990). This depression can linger from 2 to 8 yrs, depending on the severity of the bleaching event and presence of local stressors (Carilli et al. 2009; D'Olivo et al. 2013; Cantin and Lough 2014). There were no clear and obvious impacts of bleaching in the growth records of the two species examined herein, which was not surprising given the lack of severe bleaching events over this time (Johnston et al. 2019).

There is evidence, however, that coral bleaching is increasing at FGB, but to date there has not been significant mortality associated with a bleaching event (Johnston et al. 2019). The first bleaching event reported at FGB occurred in 1990 , where $4.8 \%$ of the monitored coral cover bleached (Hagman and Gittings 1992). It was noted that O. annularis and $P$. strigosa exhibited lower levels of bleaching and were less impacted than other species, which may explain the lack of clear, bleaching-induced declines in calcification in our data. Mild or moderate bleaching was reported in 1995, 2005, and 2010. Approximately 3\% of the coral cover bleached in 1995, whereas moderate bleaching of $\sim 10 \%$ coral cover was noted in 2005 (CSA 1996; Precht et al. 2008). Thermal stress in 2010 was similar to 2005; thus, bleaching was likely similar to 2005, but data for the 2010 event are not available (see Johnston et al. 2019). The most significant event occurred in 2016, where $67 \%$ of the coral cover exhibited bleaching or signs of paling (Johnston et al. 2019). Although our core data stop in 2014 and do not incorporate the recent severe event, it is important to note that there is a declining trend in extension and calcification for $P$. strigosa with each successive bleaching event, with the lowest rates occurring during the 2010 event (Fig. S1). Given the significant warming trend and documented increase in severity and magnitude of bleaching at FGB, the prognosis is that bleaching events will continue to become more and more detrimental, which will lead to the breakdown in the positive relationship between coral growth and maximum SST. It seems this may already be beginning as there are clear declines in extension and calcification associated with the 2010 bleaching event in P. strigosa (Fig. S1).

Coral extension and calcification have increased over the past 45-57 yrs at FGB, and this can be attributed to enhanced growth due to ocean warming. We have provided further evidence that high runoff from the Atchafalaya River leads to reduced coral extension and calcification at the FGB. We hypothesize that the stimulation in growth with warming at FGB will continue until coral bleaching events increase in severity and frequency. The fact that the most severe bleaching event ever recorded at FGB occurred in 2016 suggests that the increase in growth due to warmer waters is likely reaching the threshold whereby the thermal optima are exceeded, and growth declines.

Acknowledgements Funding was provided by NOAA's Coral Reef Conservation Program and Ocean Acidification Program in support of the National Coral Reef Monitoring Program. Core collections occurred under Flower Garden Banks National Marine Sanctuary Permit \# FGBNMS-2014-003. Field assistance with coring was provided by R. Carlton, R. Eckert, M. Johnston, P. Jones, and L. Valentino. We thank the captain and crew of the R/V Manta for working with us to make our intensive operations a success. DPM thanks R. van Hooidonk for assistance with SST data; J.P. Rippe for help with statistical analysis and methods for CTing brain corals; and J. Holmes and ICE for coring. The scientific results and conclusions, as well as any views or opinions expressed herein, are those of the author(s) and do not necessarily reflect the views of NOAA or the Department of Commerce.

\section{Declarations}

Conflict of interest On behalf of all authors, the corresponding author states that there is no conflict of interest.

Open Access This article is licensed under a Creative Commons Attribution 4.0 International License, which permits use, sharing, adaptation, distribution and reproduction in any medium or format, as long as you give appropriate credit to the original author(s) and the source, provide a link to the Creative Commons licence, and indicate if changes were made. The images or other third party material in this article are included in the article's Creative Commons licence, unless indicated otherwise in a credit line to the material. If material is not included in the article's Creative Commons licence and your intended use is not permitted by statutory regulation or exceeds the permitted use, you will need to obtain permission directly from the copyright holder. To view a copy of this licence, visit http://creativecommons. org/licenses/by/4.0/. 


\section{References}

Alvarez-Filip L, Dulvy NK, Gill JA, Cote IM, Watkinson AR (2009) Flattening of Caribbean coral reefs: region-wide declines in architectural complexity. Proc Roy Soc London B 276:3019-3025

Aronson RB, Precht WF, Murdoch TJT, Robbart ML (2005) Longterm persistence of coral assemblages on the Flower Garden Banks, Northwestern Gulf of Mexico: implications for science and management. Gulf Mex Sci 23:84-94

Barnes DJ, Taylor RB (2001) On the nature and causes of luminescent lines and bands in coral skeletons. Coral Reefs 19:221-230

Bennion H, Simpson GL, Goldsmith BJ (2015) Assessing degradation and recovery pathways in lakes impacted by eutrophication using the sediment record. Front Ecol Evol 3:94

Boto K, Isdale P (1985) Fluorescent bands in massive corals result from terrestrial fulvic acid inputs to the nearshore zone. Nature 315:396-397

Bright TJ, Kraemer GP, Minnery GA, Viada ST (1984) Hermatypes of the Flower Garden banks, northwestern Gulf of Mexico: a comparison to other Western Atlantic reefs. Bull Mar Sci 34:461-476

Cantin NE, Cohen AL, Karnauskas KB, Tarrant AM, McCorkle DC (2010) Ocean Warming Slows Coral Growth in the Central Red Sea. Science 329:322-325

Cantin NE, Lough JM (2014) Surviving coral bleaching events: Porites growth anomalies on the Great Barrier Reef. PLoS ONE 9:e88720

Carilli JE, Norris RD, Black BA, Walsh SM, McField M (2009) Local Stressors Reduce Coral Resilience to Bleaching. PLoS ONE 4:e6324. https://doi.org/10.1371/journal.pone.0006324

Carricart-Ganivet JP (2004) Sea surface temperature and the growth of the West Atlantic reef-building coral Montastraea annularis. J Exp Mar Biol Ecol 302:249-260

Carricart-Ganivet JP (2011) Coral skeletal extension rate: An environmental signal or a subject to inaccuracies? J Exp Mar Biol Ecol 405:73-79

Carricart-Ganivet JP, Cabanillas-Teran N, Cruz-Ortega I, Blanchon P (2012) Sensitivity of Calcification to Thermal Stress Varies among Genera of Massive Reef-Building Corals. PLoS ONE 7(3):e32859. https://doi.org/10.1371/journal.pone.0032859

Castillo KD, Lima FP (2010) Comparison of in situ and satellitederived (MODIS-Aqua/Terra) methods for assessing temperatures on coral reefs. Limnol Oceanogr: Methods 8:107-117

Castillo KD, Ries JB, Weiss JM (2011) Declining coral skeletal extension on forereef colonies of Siderastrea siderea on the Mesoamerican Barrier Reef System, Southern Belize. PLoS One 6:e14615

Castillo KD, Ries JB, Weiss JM, Lima FP (2012) Decline of forereef corals in response to recent warming linked to history of thermal exposure. Nat Clim Change 2:756-760

Chan NCS, Connolly SR (2013) Sensitivity of coral calcification to ocean acidification: a meta-analysis. Glob Change Biol 19:282-290

Contreras-Silva AI, Tilstra A, Migani V, Thiel A, Pérez-Cervantes E, Estrada-Saldívar N, Elias-Ilosvay X, Mott C, Alvarez-Filip L, Wild C (2020) A meta-analysis to assess long-term spatiotemporal changes of benthic coral and macroalgae cover in the Mexican Caribbean. Sci Rep 10:8897. https://doi.org/10.1038/ s41598-020-65801-8

Cooper TF, O'Leary RA, Lough JM (2012) Growth of western Australian corals in the Anthropocene. Science 335:593-596. https://doi.org/10.1126/science. 1214570

Courtney TA, Kindeberg T, Andersson AJ, Caroselli E (2020) Coral calcification responses to the North Atlantic Oscillation and coral bleaching in Bermuda. PLOS ONE 15(11) e0241854. https://doi.org/10.1371/journal.pone.0241854

CSA (Continental Shelf Associates) (1996) Long-term monitoring at the East and West Flower Garden Banks. US Dept of the Interior, Mineral Management Service, Gulf of Mexico OCS Study MMS 96-0046, New Orleans, Louisiana, 77

De'ath G, Lough JM, Fabricius KE (2009) Declining coral calcification on the Great Barrier Reef. Science 323:116-119. https:// doi.org/10.1126/science.1165283

Deslarzes KJ, Lugo-Fernandez A (2007) Influence of terrigenous runoff on offshore coral reefs: an example from the Flower Garden Banks, Gulf of Mexico. In: Aronson RB (ed) Geological approaches to coral reef ecology. Springer, Berlin, pp 126-160

Dodge RE, Lang JC (1983) Environmental correlates of hermatypic coral (Montastrea annularis) growth on the East Flower Gardens Bank, northwest Gulf of Mexico. Limnol Oceanogr 28:228-240

D'Olivo JP, McCulloch MT, Judd K (2013) Long-term records of coral calcification across the central Great Barrier Reef: Assessing the impacts of river runoff and climate change. Coral Reefs 32:999-1012. https://doi.org/10.1007/s00338-013-1071-8

Eakin CM, Morgan JA, Heron SF, Smith TB, Liu G, Alvarez-Filip L et al (2010) Caribbean corals in crisis: Record thermal stress, bleaching, and mortality in 2005. PLoS ONE 5:e13969

Gardner TA, Côté IM, Gill JA, Grant A, Watkinson AR (2003) Longterm region-wide declines in Caribbean corals. Science 301:958-960

Giry C, Felis T, Kölling M, Scheffers S (2010) Geochemistry and skeletal structure of Diploria strigosa, implications for coralbased climate reconstruction. Palaeogeo Palaeoclim Palaeoecol 298:378-387

Gittings SR (1998) Reef Community Stability on the Flower Garden Banks, Northwest Gulf of Mexico. Gulf of Mexico Science 16:161-169

Gittings SR, Boland GS, Deslarzes KJP, Hagman DK, Holland BS (1992) Long-term monitoring at the East and West Flower Garden Banks. US Dept of the Interior, Mineral Management Service, Gulf of Mexico OCS Study MMS 92-006, New Orleans, Louisiana, 206

Goreau TJ, Macfarlane AH (1990) Reduced growth rate of Montastrea annularis following the 1987-1988 coral-bleaching event. Coral Reefs 8:211-215. https://doi.org/10.1007/BF00265013

Groves S, Holstein D, Enochs I, Kolodziej G, Manzello DP, Brandt M, Smith TB (2018) Growth rates of Porites astreoides and Orbicella franksi in mesophotic habitats surrounding St. Thomas Coral Reefs 37:345-354. https://doi.org/10.1007/s00338-0181660-7

Guo W, Bokade R, Cohen AL, Mollica NR, Leung M, Brainard RE (2020) Ocean Acidification Has Impacted Coral Growth on the Great Barrier Reef. Geophys Res Lett 47:e2019GL086761

Hagman DK, Gittings SR (1992) Coral bleaching on high latitude reefs at the Flower Garden Banks, NW Gulf of Mexico. Proc 7th Int Coral Reef Symp 1:38-43

Helmle KP, Dodge RE, Ketcham RA (2000) Skeletal architecture and density banding in Diploria strigosa by X-ray computed tomography. Proc $9^{\text {th }}$ Int Coral Reef Symp 1:365-371

Helmle KP, Kohler K, Dodge RE (2002) Relative optical densitometry and the coral X-radiograph densitometry system: Coral XDS. Int Soc Reef Studies 2002 European Meeting, Cambridge. http://www.nova.edu/ocean/coralxds/index.html

Helmle K, Dodge R, Swart P, Gledhill DK, Eakin CM (2011) Growth rates of Florida corals from 1937 to 1996 and their response to climate change. Nat Comm 2:215. https://doi.org/10.1038/ ncomms 1222

Hu X, Nuttall MF, Wang H, Yao H, Staryk CJ, McCutcheon MR, Eckert RJ, Embesi JA, Johnston MA, Hickerson EL, Schmahl GP, Manzello DP, Enochs IC, DiMarco S, Barbero L (2018) 
Seasonal variability of carbonate chemistry and decadal changes in waters of a marine sanctuary in the Northwestern Gulf of Mexico. Mar Chem 205:16-28

Hudson JH, Shinn EA, Halley RB, Lidy B (1976) Sclerochronology: a tool for interpreting past environments. Geology 4:361-364

Hudson JH, Robbin DM (1981) Effects of drilling mud on the growth rate of the reef-building coral, Montastraea annularis. Marine Environmental Pollution Elsevier Oceanogr Ser 27A:455-470

Isdale PJ (1984) Fluorescent bands in massive corals record centuries of coastal rainfall. Nature 310:578-579

Jackson J, Donovan M, Cramer K, Lam V (2014) Status and trends of Caribbean coral reefs: 1970-2012. Retrieved from Washington, D.C. http://pubs.er.usgs.gov/publication/70115405

Johnston MA, Eckert RJ, Nuttall MF, Sterne TK, Embesi JA, Manzello DP, Hickerson EL, Schmahl GP (2017) Long-term monitoring at the East and West Flower Garden Banks National Marine Sanctuary, 2013-2015, volume 1: technical report. US Dept of Interior, Bureau of Ocean Energy Management, Gulf of Mexico OCS Study BOEM 2017-058, New Orleans, Louisiana, $186 \mathrm{p}$

Johnston MA, Hickerson EL, Nuttall MF, Blakeway RD, Sterne TK, Eckert RJ, Schmahl GP (2019) Coral bleaching and recovery from 2016 to 2017 at east and west Flower Garden Banks, Gulf of Mexico. Coral Reefs 38:787-799

Kealoha AK, Doyle SM, Shamberger KEF, Sylvan JB, Hetland RD, DiMarco SF (2020a) Localized hypoxia may have caused coral reef mortality at the Flower Garden Banks. Coral Reefs 39:119-132. https://doi.org/10.1007/s00338-019-01883-9

Kealoha AK, Shamberger KEF, DiMarco S, Thyng K, Hetland R, Manzello DP, Slowley N, Enochs IC (2020b) Surface Water $\mathrm{CO}_{2}$ Variability in the Gulf of Mexico (1996-2017). Sci Rep 10:12279. https://doi.org/10.1038/s41598-020-68924-0

Kleypas JA, McManus JW, Meñez LAB (1999) Environmental limits to coral reef development: where do we draw the line? Am Zool 39:146-159

Lough JM, Barnes DJ (1990) Intra-annual timing of density band formation of Porites coral from the central Great Barrier Reef. J Exp Mar Biol Ecol 135:35-57

Lough JM, Barnes DJ (2000) Environmental controls on growth of the massive coral Porites. J Exp Mar Biol Ecol 245:225-243. https://doi.org/10.1016/s0022-0981(99)00168-9

Lough JM, Barnes DJ, McAllister FA (2002) Luminescent lines in corals from the Great Barrier Reef provide spatial and temporal records of reefs affected by land runoff. Coral Reefs 21:333-343

Manzello DP, Enochs IC, Bruckner A, Renaud P, Kolodziej G, Budd D, Carlton R, Glynn PW (2014) Galápagos Coral Reef Persistence after ENSO Warming Across an Acidification Gradient. Geophys Res Lett 41:9001-9008. https://doi.org/10. 1002/2014GL062501

Manzello DP, Enochs IC, Kolodziej G, Carlton R, Valentino L (2018) Resilience in carbonate production despite three coral bleaching events in five years on an inshore patch reef in the Florida Keys. Mar Biol 165:99

Mollica NR, Guo WF, Cohen AL, Huang KF, Foster GL, Donald HK, Solow AR (2018) Ocean acidification affects coral growth by reducing skeletal density. Proc Natl Acad Sci USA 115:1754-1759. https://doi.org/10.1073/pnas.1712806115

Muñiz-Castillo AI, Rivera-Sosa A, Chollett I, Eakin CM, AndradeGómez L, McField M, Arias-González JE (2019) Three decades of heat stress exposure in Caribbean coral reefs: a new regional delineation to enhance conservation. Sci Rep 9:11013. https:// doi.org/10.1038/s41598-019-47307-0
NOAA Coral Program (2014) National coral reef monitoring plan. NOAA coral reef conservation program. Silver Spring, MD, p 39

NOAA Coral Program (2020) National Coral Reef Monitoring Program - Status Reports. Accessible at: https://www.coris. noaa.gov/monitoring/status_report/

Perry CT, Murphy GN, Kench PS, Smithers SG, Edinger EN, Steneck RS, Mumby PJ (2013) Caribbean-wide decline in carbonate production threatens coral reef growth. Nat Comm 4:1402. https://doi.org/10.1038/ncomms2409

Perry CT, Alvarez-Filip L, Graham N, Mumby PJ, Wilson SK, Kench PS, Manzello DP, Morgan K, Slangen ABA, Thompson DP, Januchowski-Hartley F, Smithers SG, Steneck RR, Carlton R, Edinger EE, Enochs IC, Estrada-Saldivar N, Haywood MDE, Kolodziej G, Murphy GN, Perez-Cervantes E, Suchley A, Valentino L, Boenish R, Wilson M, Macdonald C (2018) Loss of coral reef growth capacity to track future increases in sea-level. Nature 558:396-400

Precht WF, Aronson RB, Deslarzes KJP, Robbart ML, Zimmer B, Duncan L (2008) Post hurricane assessment at the East Flower Garden Bank long-term monitoring site: November US Dept of the Interior, Mineral Management Service, Gulf of Mexico OCS Study MMS 2008-019. Louisiana, New Orleans, p 39

R Core Team (2019) R: A language and environment for statistical computing. Vienna, Austria: R Foundation for Statistical Computing

Rayner N, Parker DE, Horton EB, Folland CK, Alexander LV, Rowell DP, Kent EC, Kaplan A (2003) Global analyses of sea surface temperature, sea ice, and night marine air temperature since the late nineteenth century. J Geophys Res 108:4407. https://doi.org/10.1029/2002JD002670

Rezak R, Gittings SR, Bright TJ (1990) Biotic assemblages and ecological controls on reefs and banks of the Northwest Gulf of Mexico. Am Zool 30:23-35

Rico-Esenaro SD, Sanchez-Cabeza JA, Carricart-Ganivet JP, Montagna P, Ruiz-Fernandez AC (2019) Uncertainty and variability of extension rate, density and calcification rate of a hermatypic coral (Orbicella faveolata). Sci Tot Env 650:1576-1581

Rippe JP, Baumann JH, De Leener DN, Aichelman HE, Friedlander EB, Davies SW, Castillo KD (2018) Corals sustain growth but not skeletal density across the Florida Keys Reef Tract despite ongoing warming. Glob Change Biol 24:5205-5217

Schramek TA, Colin PL, Merrifield MA, Terrill EJ (2018) Depthdependent thermal stress around corals in the tropical Pacific Ocean. Geophys Res Lett 45:9739-9747

Tanzil JTI, Brown BE, Dunne RP, Lee JN, Kaandorp JA, Todd PA (2013) Regional decline in growth rates of massive Porites corals in Southeast Asia. Glob Change Biol 19:3011-3023

Teague WJ, Wijesekera HW, Jarosz E, Fribance DB, Lugo-Fernandez A, Hallock ZR (2013) Current and hydrographic conditions at the East Flower Garden Bank in 2011. Cont Shelf Res 63:43-58

US Army Corps of Engineers (2020) River Gages.com: Water levels of rivers and lakes. Accessible at: https://rivergages.mvr.usace. army.mil/WaterControl/new/layout.cfm

Wood SN (2017) Generalized additive models: An introduction with R (2nd edition). CRC Press, Boca Raton, FL. https://doi.org/10. 1201/9781315370279

Wyatt ASJ, Leichter JJ, Toth LT, Miyajima T, Aronson RB, Nagata T (2020) Heat accumulation on coral reefs mitigated by internal waves. Nat Geosci 13:28-34

Publisher's Note Springer Nature remains neutral with regard to jurisdictional claims in published maps and institutional affiliations. 